NBER WORKING PAPER SERIES

\title{
THE SOURCES AND USES OF ANNUAL GIVING AT PRIVATE RESEARCH UNIVERSITIES
}

\author{
Ronald G. Ehrenberg \\ Christopher L. Smith \\ Working Paper 8307 \\ http://www.nber.org/papers/w8307 \\ NATIONAL BUREAU OF ECONOMIC RESEARCH \\ 1050 Massachusetts Avenue \\ Cambridge, MA 02138 \\ May 2001
}

Ehrenberg is the Irving M. Ives Professor of Industrial and Labor Relations and Economics and Director of the
Cornell Higher Education Research Institute (CHERI) at Cornell University. Smith is a sophomore in Cornell's
School of Industrial and Labor Relations. The ordering of our names reflects only alphabetical order. We are
grateful to the Andrew W. Mellon Foundation and other donors for supporting our research through their support
of the CHERI and to David Morgan, Vice President of the Council for Aid to Education (CAE) for granting us
access to the data files that underlie the CAE's annual Voluntary Support of Education publication. The views
expressed herein are those of the authors and not necessarily those of the National Bureau of Economic Research.

(C) 2001 by Ronald G. Ehrenberg and Christopher L. Smith. All rights reserved. Short sections of text, not to exceed two paragraphs, may be quoted without explicit permission provided that full credit, including (C) notice, is given to the source. 
The Sources and Uses of Annual Giving at Private Research Universities

Ronald G. Ehrenberg and Christopher L. Smith

NBER Working Paper No. 8307

May 2001

JEL No. I22, L3

\begin{abstract}
Private research universities differ in the shares of their annual giving coming from different sources (alumni, other individuals, foundations, corporations) and the shares of their annual giving applied to different uses (current operations, buildings and equipment, enhancing their endowments). After providing background data on the aggregate variation in these shares over time and their interuniversity variation at a point in time, our econometric analyses use data from a panel of research universities that span a 30-year period to provide explanations for these differences. These differences are seen to depend upon institutional characteristics, macroeconomic variables and tax parameters. One key finding is that richer institutions, as measured by endowment per student, devote a larger share of their annual giving to further building their endowments. This contributes to the increasing dispersion of wealth across private research universities.
\end{abstract}

Ronald G. Ehrenberg

Cornell Higher Education Research Institute (CHERI)

ILR - Cornell University

256 Ives Hall

Ithaca, NY 14853-3901

and NBER

rge2@cornell.edu
Christopher L. Smith

CHERI

ILR - Cornell University

256 Ives Hall

Ithaca, NY 14853-3901

cls39@cornell.edu 


\section{Introduction}

In 1998-99, Cornell University and Duke University were ranked second and third in the nation, respectively, in terms of the volume of giving each received from external donors. That year Cornell reported receiving \$341.3 million in annual giving and Duke reported receiving $\$ 331.0$ million. ${ }^{1}$ The similarity in the total volume of giving that the two institutions received is actually very misleading. Fifty-four percent of Cornell's gift total came from alumni, while only $15.3 \%$ of Duke's gift total came from alumni.

Similarly, 79.7\% of Cornell's gift total came from individuals (alumni plus other individuals) while only $26.2 \%$ of Duke's gifts came from individual donors. Cornell's giving is clearly much more dependent on individuals than is Duke's and Duke's is much more dependent in turn on corporations and foundations.

Institutions differ not only in the sources of their annual giving but also in their uses of such funds. For example, during the 1993-94 to 1997-98 period, the average percentages across 78 private research universities of annual giving devoted to current expenditures, building and equipment, and enhancing the endowment were $53.5 \%, 14.5 \%$ and $31.5 \%$, respectively. ${ }^{2}$ However, there was wide variation across the institutions in each of these percentages, with the standard deviations of these percentages being 16.9, 12.1 and 15.5 , respectively.

\footnotetext{
1 “ Chronicle of Higher Education (2000).

2 Authors' computations from data collected by the Council for Aid to Education each year and reported in their annual publication Voluntary Support to Education. We are grateful to David R. Morgan, Vice President, Research and Information Services at the CAE for granting us access to electronic versions of these reports for the 1969 to 1998 period.
} 
Our paper addresses why private research universities differ in the sources and uses of their annual giving. The next section provides some background data on the trends and variations in the shares of annual giving coming from and going to different uses. We then use data from a panel of private research universities for the 1968-69 to 1998-99 period to estimate models that provide explanations for why the levels and shares of giving coming from different sources and going to different uses vary across institutions and over time. Our explanations focus both on differences in characteristics of the institutions and differences in macroeconomic variables, such as changes in federal estate, corporate, and capital gains tax rates.

\section{Some Background Data}

Table 1 presents data on the mean shares of contributions received by seventy-eight private research universities that came from alumni, other individuals, foundations and corporations during the $1969-70$ to $1998-99$ period. The data have been grouped by 5year intervals to eliminate year-to-year fluctuations. The sum of the shares across the four sources is less than one because other sources of voluntary giving, such as religious organizations and fund raising consortia, are not included in the table. Data are also presented in the table for a subset of thirty major private research universities that have been consistently ranked among the top national universities by U.S. News \& World Report in its annual rankings of undergraduate institutions.

The alumni giving share has grown for both the entire set and the subset of thirty institutions during the period. The shares of giving from other individuals and 
foundations appear to have declined slightly. The share of giving from corporations has fluctuated during the period.

Similar data on the shares of giving going to different uses appears in table $2 .{ }^{3}$ The share of giving going to current operations first increased and then decreased during the period. After remaining relatively constant during the first 20 to 25 years of the period, the share going to endowment increased sharply during the last 5 years. Finally, the share going to buildings fell sharply after the first 5 years of the period and has remained roughly constant since then.

These tables report the mean shares across institutions for whatever institutions reported data to the Council for Aid to Education in a given year. In some years, some institutions fail to report complete data and they are excluded from the tabulations in those years. An alternative way of looking at the data is to use data for a subset of institutions that always reported complete data. This is done in figures one through seven in the appendix, where the mean shares across institutions of the sources and of the uses of giving are plotted annually. These figures convey the same story as tables 1 and 2 do.

Focusing on the changes over time in the mean shares of the sources and uses of giving across private research institutions obscures the much wider variation in these shares that occur across institutions during any period of time. To illustrate this point, table 3 displays for the 30 selected national private research universities, the means (across institutions), the standard deviation, and the minimum and maximum values of the shares of total giving attributed to various sources and of the shares of annual giving

\footnotetext{
${ }^{3}$ The definition of these shares has varied over time. Up until 1998, all deferred gifts were classified as gifts to endowment. Since 1998, deferred gifts have been classified according to their intended uses. Similarly, gifts to pay interest costs on loans were recorded under gifts to capital until 1984. Since that date,
} 
that went to various uses during the 1994-95 to 1998-99 period. The standard deviations of the shares across institutions are sizable, as are the ranges between the minimum and maximum values. For example, while the mean percentage of giving across institutions that came from corporations was $16.9 \%$ during the period, the standard deviation was $8.9 \%$ and the corporate giving percentage ranged across institutions from $4.6 \%$ to $47.9 \%$ of total giving. Similarly, while on average these institutions allocated $36.2 \%$ of their giving to building their endowments, the share devoted to endowment varied from a low of $11.4 \%$ to a high of $75.9 \%$ across the institutions during the period. Other factors held constant, institutions that devote larger shares of their annual giving to endowment will have more rapid growth rates of their endowment. We shall show that institutions with larger endowments per student tend to devote larger shares of their annual giving to enhancing their endowments. This helps explain the increased dispersion in the distribution of endowment values that has been observed in recent years.

\section{Analyzing The Determinants of the Sources and Uses of Giving}

Building a structural model of the sources and uses of giving is a task that goes far beyond this paper. The institutional/year observations that we have access to on the sources and uses of giving are the result of a complex process that depends upon macroeconomic forces such as tax laws, stock market performance and income growth at the national level (Clotfelter, 1985). It also depends upon the economic success of graduates of an institution, which may well depend upon the types and numbers of

\footnotetext{
they have been recorded in a separate loan category. As, table 3 indicates, loans do not constitute an
} important share of the use of donated funds across these institutions. 
students who were admitted to and graduated from the institution many years earlier (Cochi Fiano and Cunningham, 2001).

Donors may have preferences for certain types of activities and this may influence how the gifts that institutions receive are allocated. However, two cautions are in order here. First, the major private research universities devote considerable resources to cultivating donors and "shaping" their giving preferences. So if a donor gives a restricted gift, this does not necessarily impose any restrictions on what the institution actually does with the funds. For example if an institution is trying to increase its expenditures on undergraduate grant aid so that it can more vigorously compete for students, a new external gift that is restricted to undergraduate grant aid may simply displace funds that the institution would have spent on grant aid out of its general revenues. Hence the net effect of the gift may actually be to increase expenditures on some other category of spending, or to increase the endowment. Second, if an institution decides that it needs to build a new facility for scientific research, a gift subsequently received by it that is restricted to funding construction of the facility, although restricted in name, poses no real restrictions on the institution.

With limited resources at its disposal, the development office, or using more current terms the "institutional advancement" office, of the university must decide how to allocate its staff time across donors. Some institutions believe that building and cultivating alumni support is most important. Others may feel that their alumni base is not sufficiently large or wealthy and devote resources to cultivating other individual donors. Still others may focus their efforts on seeking corporate or foundation support. Since the propensities of alumni, corporations and foundations to make contributions for 
different types of activities differ, how the institution allocates is development staff may depend upon the nature of the uses that it has for the annual giving. ${ }^{4}$

The wealth of an institution, as measured by endowment per student, may also influence annual giving for a number of reasons. The value of an endowment changes over time due to the market performance of an institution's portfolio, the share of the endowment assets that the institution spends, the level of contributions that it receives from external donors each year, and the fraction of those contributions that are directed towards building the endowment. Thus the level of the endowment at a point in time depends upon past levels of contributions to the university and their uses. To the extent that the levels of contributions and their uses are correlated over time for an institution, the correlation between the endowment per student level and the sources and uses of annual giving may run from giving sources and uses to endowment per student value, rather than visa versa.

On the other hand, there may be real behavioral reasons why higher endowment per student levels may influence giving sources and uses. Success breeds success and it may be easier to raise money the more an institution already has. Recently, however, concern has been expressed that high endowment per student levels, or more precisely high growth rates of endowments, may cause some individual donors to decide to reallocate their gifts to other "more needy" charities (Sharon Oster, 2001). Hence

\footnotetext{
${ }^{4}$ For example, the CAE reported that in $1995-96$ nationally $55 \%$ of the gifts to academic institutions were used for current operations, $30.8 \%$ were used to enhance endowments, and $14.2 \%$ went to purchase or build buildings and equipment. The percentages of corporate giving to the three uses were, respectively, $71.8 \%$, $11.2 \%$ and $17.0 \%$, while the comparable percentages for foundation giving were, $63.9 \%, 20.1 \%$ and $16 \%(\mathrm{CAE}, 1997)$. So foundation and corporation gifts are more likely to be used for current operations and buildings than are gifts from individuals.
} 
increasing endowment values may cause the share of giving coming from different sources to change.

Corporations and foundations may have distinct preferences as to the type of institutions to which they provide funding. Foundations may have special interests in providing funding for institutions that educate a large share of underrepresented minority students. Corporations use annual giving to connect themselves to institutions from which the heavily recruit students and from which they make use of faculty research, and so the distribution of undergraduate majors and the split between graduate and undergraduate students may be important. The presence of a medical school at an institution may also be important for the same reasons.

\section{Econometric Models.}

Our analyses use thirty-one years of annual data from the 1968-1969 to 1998-99 period at the institutional level for private research universities. The restriction to private research universities was made so that the sample would be as homogeneous as possible in terms of objectives and activities. Our basic methodological approach is to estimate level and share equations of the form:

(1) $\log \left(\mathrm{G}_{\mathrm{it})}=\mathrm{a}_{0}+\mathrm{a}_{1} \mathrm{X}_{\mathrm{it}}+\mathrm{a}_{2} \mathrm{Z}_{\mathrm{t}}+\mathrm{a}_{3} \mathrm{Y}_{\mathrm{i}}+\epsilon_{\mathrm{it}}\right.$ and

(2) $\log \left(S_{i t} /\left(1-S_{i t}\right)\right)=b_{0}+b_{1} X_{i t}+b_{2} Z_{t}+b_{3} Y_{i}+v_{i t}$. 
In equation (1) $\mathrm{G}_{\mathrm{it}}$ is the real (inflation adjusted level) of giving in a category (source or use) at institution $\mathrm{i}$ in period $\mathrm{t}$, the $\mathrm{X}$ are a vector of variables that vary across institutions and over time, the $\mathrm{z}$ are a vector of national level variables that vary with time but not across institutions, the $\mathrm{Y}$ are a vector of variables that vary across institutions but not over time, and the $E$ are random error terms. In equation (2), $\mathrm{S}_{\mathrm{it}}$ is the share of giving (source or use) at institution $\mathrm{i}$ in period t. The dependent variable in this equation is the $\log$ of the share ratio $(\mathrm{S} /(1-\mathrm{S}))$ to permit the error term in the equation to potentially be normally distributed.

The interpretation of the coefficient estimates obtained when one estimates these models depends critically on the assumptions made about the error terms. If one treats the error terms as being independent, both over time and across observations, then the estimates will capture both time-series and cross-section variations in the relationship between the share variables and the explanatory variables that vary both over time and across observations. For example, the coefficient of endowment per student will capture the impact of both differences across institutions in endowment per student and the impact of changes in endowment per student at a given institutions.

On the other hand, if one treats the error terms as having a component that is fixed over time for a given institution but that varies across institutions, the resulting coefficient estimates will capture the intertemporal variation between these explanatory variables and the shares. Finally, if one treats the error term as having a component that is fixed across institutions at a point in time, but that varies over time, the resulting coefficient estimates will capture primarily the cross institution relationship between the explanatory variables and the shares. We focus on the first type of estimates in the next 
two sections and discuss the sensitivity of our findings to the assumptions made about the error structures in the following section.

\section{Determinants of the Sources of Annual Giving}

Table 4 presents estimates of equations (1) using data from a sample of 78 private research universities for the 1968-79 to $1998-99$ period. A list of variable definitions is appended to the table and the appendix tables provides information on the sources of each variable used in the analysis, as well as descriptive statistics. ${ }^{5}$

Turning first to a set of tax rate measures, increases in the federal capital gains tax rate are associated with a decrease in both alumni giving and other individual giving. For individuals associated with these institutions, the income effect of an increase in the capital gains tax (lower after tax income) dominates over the price effect of the increase in the tax. Increases in the estate tax are associated with higher foundation giving to these institutions. One possible explanation for this result is that more foundations are established when estate taxes are high and then foundation giving increases because the tax law "encourages" foundations to give away at least $5 \%$ of their assets each year. We find no evidence, however, that changes in the corporate tax rate influence corporate giving to these institutions. ${ }^{6}$

It is well known that a large share of alumni giving to an institution is concentrated among a small number of wealthy donors. For example, in 1995-96 gifts

\footnotetext{
${ }^{5}$ The estimates presented in tables 4 through 7 do not allow for the correlation of error terms across years or institutions. Estimation of random effects models that allowed for institutional and year components of error terms marginally reduced the statistical precision of the estimates but did not alter the pattern of findings.
} 
from trustees of academic institutions accounted for almost $15 \%$ of the gifts the institutions received from alumni and other individuals (Council for Aid to Education, 1997). One, albeit imperfect, measure of the number of wealthy alumni associated with an institution is the number of its alumni who are CEOs of Fortune 500 companies. $^{7} \mathrm{We}$ find that every additional CEO is associated with the level of a real alumni giving being $1 \%$ higher. $^{8}$

U.S. News \& World Report has been ranking national research universities since the late 1980s. For each year that the ranking data was available we grouped the institutions into the top 25 , the remainder of the first quartile, the second quartile, and the third quartile. ${ }^{9}$ With the top 25 being the omitted category, the coefficients of the quartile or tier dichotomous variables suggest that alumni, foundation and corporate giving are all highest at the top tier institutions.

The disciplinary composition of undergraduate students' degrees at each institution also influences giving. Other things equal, the greater the share of undergraduate degrees granted to students in engineering fields, the lower are other individual and foundation giving but the greater is corporate giving. Similarly, the greater the share of undergraduate degrees granted to students in business related fields, the lower are alumni and foundation giving and the higher is corporate giving. Larger

\footnotetext{
${ }^{6}$ The maximum marginal federal personal income tax rate was very highly correlated with the maximum estate tax rate and the capital gains tax rate. To avoid collinearity problems, this variable is omitted from the estimating equations.

${ }^{7} \mathrm{We}$ count the number of CEOs with undergraduate degrees from each institution and the number with MBA degrees. If a CEO has two degrees from the same school this may seem like double counting. Our justification is the belief that CEOs who have two degrees from an institution are likely to give more to the institution than comparable CEOs who have one degree from that institution and a second degree from another institution.

${ }^{8}$ We are grateful to Professor Kevin J. Murphy of Southern California University for providing us with these data for the period prior to 1990. We collected the later years' data ourselves from Fortune.

${ }^{9}$ The few private research universities that ever appeared in the $4^{\text {th }}$ quartile were excluded from our sample.
} 
institutions, as measured by enrollment levels, and wealthier institutions, as measured by endowment per student, also receive higher levels of giving from all sources.

Real median family income and the Standard and Poor's stock market index were very highly correlated during the sample period. To reduce collinearity problems, the logarithms of income and the ratio of the stock market price index to income are entered into the equation. The coefficient estimates for these variables suggest that holding the ratio of stock market prices to income constant, changes in real median family income are not associated with increases in any form of giving. However, holding income constant, changes in the ratio, which mean changes in the Standard and Poor's index are positively associated with alumni giving and, inexplicably, negatively with Foundation giving.

Turning to other characteristics of the university, an increase in the level of research expenditures per faculty member is associated with higher levels of all types of giving but the association is weakest for alumni giving. The greater the share of the student body that is female, the lower is the level of alumni giving, perhaps reflecting historically lower incomes and labor force participation rates for female than male graduates of the institutions, but the higher is the level of foundation giving.

Finally, the larger the number of alumni per enrolled student, the higher is the level of alumni giving, but the lower is the level of other individual giving. The growth in the alumni/student ratio that has taken place nationally at many institutions, due to historic patterns of growth in the size of their student bodies, is among the factors that have caused alumni giving to rise as a share of total giving at many institutions. The negative relationship between the alumni/student ratio and other individual giving is undoubtedly due to the fact that development offices with large alumni bodies do not 
have to devote as much of their resources to making connections to other individual donors ${ }^{10}$.

Our concern is ultimately not with the levels the sources of giving that different institutions receive but with the shares of giving. So in table 5 we present the results of estimating equations (2): the determinants of the log share ratios for the various forms of giving. The key results follow directly from the signs and magnitudes of various coefficients in the level equations.

Turning first to the national level variables that affect all institutions, other factors held constant, an increase in the estate tax leads to an increase in the share of foundation giving and a corresponding decease in the share of corporate giving. When real median family income goes up, holding constant the ratio of the Standard and Poor's index to real median family income, the share of corporate giving declines. In contrast, holding median family income constant, when the Standard and Poor's index rises relative to median family income, the share of foundation giving declines.

Turning next to the institutional variables that vary over time, an increase in the number of CEOs who have degrees from the institution is associated with a greater share of alumni giving and smaller shares of foundation and corporate giving. The share of degrees granted to students in engineering is positively associated with the shares of alumni and corporate giving, but negatively associated with the shares of foundation and other individual giving. Similarly, the greater the share of degrees granted to students in business, the greater the share of corporate giving but the smaller the share of foundation giving. The composition of the student body between graduate and undergraduate

\footnotetext{
${ }^{10}$ For brevity, we do not discuss here the relationships that we also found between the various types of giving, having a medical college, being affiliated with a religious denomination, and the share of the
} 
students also matters. Other factors held constant, the greater the share of students who are undergraduates, the greater the share of alumni giving and the smaller the share of corporate giving.

The racial/gender/ethnic make-up of the student body also influences the pattern of giving. An increased share of female students is associated with an increased share of giving from foundations, but a decreased share of giving from corporations and alumni. An increased share of underrepresented minority students is associated with an increased share of giving from foundations. Larger institutions, as measured by enrollments, receive a smaller share of their giving from other individuals and larger shares from all other sources, while an increase in research dollars per faculty member is associated with greater shares of foundation and corporate giving, but a smaller share of alumni giving. ${ }^{11}$ Institutions with larger endowments per student tend to get a greater share of their giving from foundations and a smaller share from corporations. In contrast, increases in the alumni/student ratio do not significantly alter the shares of giving coming from foundations and corporations, but lead to an increase in the share of giving coming from alumni and a decrease in the share coming from other individuals. Institutions with medical colleges receive a smaller share of their giving from alumni and foundations and a greater share of their giving from other individuals, while institutions that are affiliated with a religious denomination, receive more of their giving from alumni, but less of their giving from foundations.

\footnotetext{
institution's students that are undergraduates.

${ }^{11}$ Returning to the question that motivated the paper, this is one of the key factors that distinguish Cornell and Duke. In 1996, Duke's research expenditures per faculty member were about 1.75 times Cornell's value. This undoubtedly reflected Cornell's much smaller biomedical research enterprise.
} 


\section{Determinants of the Uses of Annual Giving}

Table 6 presents estimates of the determinants of the levels of annual giving that are used for current operations, to build the endowment and for buildings and equipment. The explanatory variables in these models are identical to those in the sources of giving equations. Inasmuch as we have already indicated that the distribution of giving by uses varies nationwide by the source of giving, an alternative would be to estimate "structural" models that included the shares of giving from different sources as explanatory variables. However, such a model would be fraught with simultaneity problems because the sources that development officers approach for giving depend upon the expected uses of the funds. In the absence of our being able to construct a model that treats both the shares of giving from different sources and the shares of giving used for different purposes as endogenous, we have opted for the simpler reduced form approach.

Higher capital gains taxes, which were seen in table 4 to reduce giving from alumni and other individuals are seen to be associated with reduced contributions to endowment. Increases in real median family income, holding the ratio of Standard and Poor's index to real median family income constant, are associated with more giving for endowment. In contrast, holding median real family income constant, increases in the Standard and Poor's index relative to median real family income are associated with increases in the level of giving for building and equipment.

Having more CEO's as alumni, which is associated with more alumni giving, is associated with more giving for current expenditure and more giving for endowment. The 
lower ranked research universities, as measured by their USNWR ranking receive less giving for each purpose, other factors held constant than the highest ranked institutions.

The composition of the student body also influences how giving is used. The greater the share of undergraduate students receiving degrees in engineering, the smaller the level of giving for current operations and endowments, but the larger the level of giving for building and equipment. This clearly reflects the great need by engineering students and faculty for modern teaching and research facilities. Similarly the greater the share of undergraduate students receiving degrees in business, the greater the giving for buildings and equipment, which reflects the "arms race" of spending that business schools are engaged in to attract top students (Ehrenberg 2000, chapter 4). The greater the share of students who are undergraduates, the more annual giving that comes for endowment purposes, while having a medical college is associated primarily with an increase in giving for current purposes.

Richer institutions, as measured by endowment per student, receive more giving for all purposes. However, the elasticity of giving with respect to endowment per student is much larger for endowments than it is for the other two uses of funds. This implies, which we will confirm shortly, that not surprisingly a greater share of the giving of the richer institutions goes towards building their endowments.

An increase in the female share of students is associated with more giving for buildings and equipment but less giving for endowment. In contrast, an increase in the proportion of underrepresented minority students is associated with more giving for current purposes and less giving for buildings and equipment. To the extent that minorities come from families with lower family incomes this may reflect their increased 
need for financial aid. Quite strikingly, an increase in the alumni/student ratio is associated with an increase in giving for current purposes but no significant changes in giving either for endowments or buildings and equipment.

Once again, we present estimates of the logarithm of share ratio equations to see clearly how changes in the right hand side variables influence the share of giving that goes to the various uses. These estimates are found in table 7.

Higher capital gains taxes are associated with a smaller share of giving going to endowment enhancement; all other tax variables proved statistically insignificant in this share model. When real median family income increases, holding the ratio of Standard and Poor's index to real median family income constant, the share of giving going to endowment increases while the share of giving going to buildings and equipment decreases. In contrast, when the Standard and Poor's index rises relative to real median family income, the share of giving going to buildings and equipment increases and the other two shares decrease.

Turning to the composition of the student body, a greater share of either engineering or business undergraduate students is associated with a greater share of giving being used for buildings and equipment. A greater share of female student is associated with a greater share of giving going for buildings and equipment, but a smaller share going for endowments. In contrast, a greater share of underrepresented minority students is associated with a greater share of giving going for current operations and a smaller share going for buildings and equipment. As noted above, this may reflect the greater financial need of underrepresented minority students. Finally, a greater share of undergraduate students is associated with a greater share of giving for endowment and a 
smaller share of giving for buildings and equipment, while the presence of a medical school at the institution is associated with a greater share of giving going to current operations at the expense of both of the other shares.

Richer institutions, as measured by endowment per student, devote a larger share of their annual giving to building their endowments still further and devote a smaller share of their annual giving to current operations. In contrast, institutions that have more alumni per student devote a greater share of their annual giving to current operations and smaller shares to endowment and buildings and equipment purposes.

\section{Robustness of Our Findings}

In this section we report the results of various extensions designed to ascertain how robust our findings are to the sample of institutions chosen and the assumptions made about the error terms in the model. For brevity, we summarize here only the results of our reanalyses of the sources' shares and uses' shares of annual giving.

Our analyses utilize data from a sample of 78 private research universities. The parameter estimates for the institutions constantly ranked among the top 30 national universities by U.S News \& World Report may differ from those for the rest of the sample. To test if this was indeed the case, we reestimated share models similar to those whose coefficients are reported in tables 5 and 7 , restricting the sample to those institutions that are consistently included in the top 30 by USNWR.

In the main, the parameter estimates obtained from this restricted sample were very similar to those found in tables 5 and 7. However, there were some differences. In contrast to the all sample results, an increase share of business students was associated 
with a greater share of alumni giving. The presence of a medical school was associated with an increased share of alumni giving and a decreased share of other giving, rather than visa versa. Similarly, having a religious affiliation was associated with a greater share of foundation giving and a smaller share of corporate giving, rather than visa versa.

We next focused on the assumptions made about the error structure of the models. The estimates reported in tables 5 and 7 treat the error terms as being independent across institutions and over time. As a result, they capture both time-series and cross-section variations in the relationships between the sources and uses' shares and the explanatory variables. If instead, we treat the error terms as having a component that is fixed over time for a given institution, but that varies across institutions, the resulting coefficient estimates capture only the intertemporal variation between the explanatory variables and the shares. In contrast, if we treat the error terms as having a component that it is fixed across institutions at a point in time but that varies across time, the resulting coefficient estimates will capture primarily the cross institution relationship between the explanatory variables and the shares.

When we reestimated the share models including year fixed effects, none of the coefficients of the variables that varied across institutions at a point in time switched sign and statistical significance. However, when we reestimated the share models including institutional fixed effects some important differences were observed. Turning first to the sources of giving equations, without the institutional fixed effects, an increase in the share of undergraduate students receiving degrees in engineering was associated with higher shares of giving coming from alumni and corporate sources, but lower shares of giving coming from other individuals and foundations. With the fixed effects included, an 
increase in the share of engineering students was associated with a smaller share of giving coming from alumni. Without the institutional fixed effects, a greater share of students receiving degrees in business was associated with a larger share of giving coming from corporations. However, once the institutional fixed effects were included, this relationship became negative. Finally without the institutional fixed effects, an increase in the proportion of minority students was associated with a smaller share of corporate giving, while with the inclusion of the institutional fixed effects this relationship vanished.

Turning to the uses of giving equations, without the institutional fixed effects higher shares of undergraduate degrees granted in engineering and business and a lower share of minority students were all associated with higher shares of giving being devoted to buildings and equipment. However, once the institutional fixed effects were included, these relationships all flipped sign. Thus saying that across institutions there is a positive correlation between an explanatory variable and a share does not imply that that relationship will necessarily be observed in a time-series, at least for a subset of the explanatory variables in our models.

\section{I. Concluding Remarks}

Our paper has provided an initial effort to analyze differences in the shares of the sources of giving coming from different sources and differences in the shares of giving going to different uses, both across private research universities and over time. In future research, we plan on extending our analyses to consider the sources and uses of giving received by private liberal arts colleges and public institutions. 
While some of the findings presented in this paper are sensitive to the assumptions made about the error terms in the models many are not. Among our important findings, on the sources of giving side, we find evidence that higher gains tax rates are associated with lower levels of giving from alumni and other individuals. On the uses of giving side, we find that a higher endowment per student is associated with a smaller share of giving being used for current operations and a larger share of giving being used to enhance the endowment. So one of the reasons for the growing dispersion of endowment wealth across private research universities is that the richer institutions devote a greater share of their annual giving to growing their endowment still further.

Can our findings shed light on the great disparity that we opened our paper with in the shares of giving that Cornell (.540) and Duke (.153) received from their alumni in 1998-99? At the time we wrote this draft of the paper, data on several of the explanatory variables utilized in the models were not available for 1998-99. However, we have data on all of the explanatory variables for 1997-98 when the differential in their shares of giving coming from alumni was almost as large (.505 vs. .168) and we will focus on this difference.

A perusal of the values of the explanatory variables indicates that there were many factors that our model predicts caused Cornell's share of giving from alumni to be higher than Duke's share. Cornell's alumni included more Fortune 500 CEOs. Cornell had a greater share of degrees granted in engineering fields, a greater total enrollment, a greater share of degrees granted to undergraduate students and more alumni per student. In contrast, Cornell also had a lower level of research spending per faculty member, which reflected its smaller biomedical research enterprise. The models predict that this 
last variable should have decreased Cornell's share of giving from alumni relative to Duke's share.

The first row of table 8 summarizes the impact of all of these factors. Column 1 shows Cornell's actual share of giving from alumni in 1997-98, .505. Inasmuch as Cornell and Duke are both included in our top 30 sample, we use the estimates of the logarithm of the share of alumni giving divided by one minus the share of alumni giving equations estimated using this subgroups data; this equation is found in appendix table 3. ${ }^{12}$ Substituting each of the values of the explanatory variables for Cornell for 1997-98 into that equation and solving for Cornell's predicted from the model share of giving from alumni in that year, we obtain a predicted value of .382 in column 2. Similarly, substituting each of the values of the explanatory variables for Duke for 1997-98 into the equation and solving for Duke's predicted value, we obtain a predicted value for Duke of .312 in column 3. While this is less than Cornell's predicted value for the share of giving from alumni in the year, it also is greater than Duke's actual value for the share of giving from alumni of .168 in the year (column 4). So while the model does predict that Cornell should have a larger share of alumni giving than Duke, it under predicts the differential in that year.

Similar simulations can be done to contrast Cornell's and Duke's predicted shares of giving from other sources in 1997-98 using the coefficients of the other share equations found in appendix table 3 . These results are found in the remaining rows of table 8 . In each case, the model correctly predicts the relationship between Cornell and Duke's shares of giving from the various sources in 1997-98. However, for each of the

\footnotetext{
${ }^{12}$ Because we are interested here in explaining the cross institution variation in the shares, models that include institutional fixed effects are not relevant here.
} 
three shares, the predicted differential in the share is less than the actual differential that occurred. So while our model can "explain" part of the differences in the shares of giving received by Cornell and Duke from different sources in 1997-98, it cannot explain the entire difference in these shares. 


\section{References}

Charles Clotfelter, Federal Tax Policy and Charitable Giving (Chicago IL: University of Chicago Press, 1985)

Ronald G. Ehrenberg, Tuition Rising: Why College Costs So Much (Cambridge MA: Harvard University Press, 2000)

Carlena K. Cochi Ficano and Brendan M. Cunningham, "The Determinants of Donative Revenue from Alumni of Higher Education: An Empirical Inquiry" (working paper, Department of Economics, Hartwick College, February 2001) (paper prepared for the Cornell Higher Education Research Institute Conference on "Financing Higher Education Institutions in the $21^{\text {st }}$ Century", Ithaca NY, May 21, 2001)

Sharon M. Oster, "The Effect of University Endowment Growth on Giving: Is there Evidence of Crowding Out?” (working paper, Yale School of Management, New Haven CT, February 2001) (paper prepared for the Cornell Higher Education Research Institute Conference on "Financing Higher Education in the $21^{\text {st }}$ Century", Ithaca NY, May 21, 2001)

Voluntary Support of Education, 1996: Institutional Data (New York, NY:

Council for Aid to Education, 1997).

"Voluntary Support of Education, 1999”, Chronicle of Higher Education, May 5, 2000. 


\section{Table 1}

Mean Share of Contributions by Private Universities Coming From Different Sources

Seventy-Eight Private Universities

\begin{tabular}{|c|c|c|c|c|}
\hline Years & Alumni & Other Individuals & Foundations & Corporations \\
\hline $69-73$ & 0.24 & 0.28 & 0.23 & 0.19 \\
\hline $74-78$ & 0.25 & 0.24 & 0.25 & 0.18 \\
\hline $79-83$ & 0.25 & 0.23 & 0.23 & 0.21 \\
\hline $84-88$ & 0.26 & 0.24 & 0.20 & 0.23 \\
\hline $89-93$ & 0.28 & 0.24 & 0.21 & 0.20 \\
\hline $94-98$ & 0.30 & 0.25 & 0.21 & 0.18 \\
\hline
\end{tabular}

Source: Authors' estimates from data provided by Council for Aid to Education

Note: Shares per period do not sum to one because there are other sources of fundraising income that VSE incorporates into its survey.

We did not calculate shares for these other sources (I.e. religious organizations, 'fundraising consortia,' etc.). 
Table 2

Mean Share of Contributions by Private Universities Going to Different Uses

\section{Eighty Private Universities}

\begin{tabular}{lccc}
\hline Years & Current & Buildings & Endowment \\
\hline $69-73$ & 0.52 & 0.21 & 0.26 \\
$74-78$ & 0.58 & 0.16 & 0.26 \\
$79-83$ & 0.56 & 0.17 & 0.26 \\
$84-88$ & 0.56 & 0.19 & 0.25 \\
$89-93$ & 0.55 & 0.16 & 0.28 \\
$94-98$ & 0.53 & 0.14 & 0.31
\end{tabular}

Source: Authors' estimates from data provided by the Council for Aid to Education 
Table 3

Shares of giving coming from different sources and going to different uses at $\mathbf{3 0}$ major private research universities during the 1994-1995 to $1998-1999$ period* $^{*}$

Sources

Mean St. Dev Min Max

\begin{tabular}{|l|l|l|l|l|}
\hline Alumni & 0.349 & 0.145 & 0.060 & 0.834 \\
\hline Individuals & 0.193 & 0.088 & 0.017 & 0.652 \\
\hline Foundations & 0.239 & 0.108 & 0.037 & 0.603 \\
\hline Corporations & 0.167 & 0.089 & 0.046 & 0.479 \\
\hline
\end{tabular}

Uses

\begin{tabular}{|l|l|l|l|l|}
\hline Current Expenditures & 0.505 & 0.128 & 0.180 & 0.759 \\
\hline Endowment & 0.369 & 0.117 & 0.146 & 0.759 \\
\hline Buildings / Equipment & 0.124 & 0.082 & 0.012 & 0.416 \\
\hline Loans & 0.003 & 0.008 & 0.000 & 0.060 \\
\hline
\end{tabular}

Source: Authors' estimates from data provided by the Council for Aid to Education

* The institutions in the sample are listed in Table 1 


\section{Table 4}

Logarithm of Real Giving Received From Different Sources:

78 Private Research Universities 1968-69 to 1998-99a

(absolute value of t-statistics in parentheses)

\section{Other Individual}

Alumni Giving $\quad$ Giving Foundation Giving Corporate Giving

\begin{tabular}{lccccc}
\hline GAIN TAX & $-0.019(2.4)$ & $-0.034(2.4)$ & $-0.012(1.2)$ & \\
EST TAX & $0.002(.3)$ & $0.007(.6)$ & $0.018(2.0)$ & $-0.004(1.1)$ \\
CORP TAX & & & & \\
CEO & $0.011(6.4)$ & $0.005(1.6)$ & $0.000(.1)$ & $0.000(.1)$ \\
TIER1 & $-0.241(2.9)$ & $-0.214(1.5)$ & $-0.214(2.0)$ & $-0.224(2.8)$ \\
TIER2 & $-0.595(7.7)$ & $0.005(.0)$ & $-0.316(3.2)$ & $-0.580(7.7)$ \\
TIER3 & $-0.540(6.3)$ & $-0.322(2.1)$ & $-0.418(3.8)$ & $-0.407(4.8)$ \\
SENG & $-0.107(.6)$ & $-1.995(6.8)$ & $-1.184(5.5)$ & $1.550(9.8)$ \\
SBUS & $-0.332(1.5)$ & $-0.271(.7)$ & $-0.652(2.3)$ & $0.923(4.3)$ \\
LENR & $0.946(32.1)$ & $0.289(5.6)$ & $0.723(19.1)$ & $0.871(30.5)$ \\
LENDSTU & $0.430(26.4)$ & $0.424(14.8)$ & $0.600(28.7)$ & $0.336(21.2)$ \\
LINCOME & $0.923(1.2)$ & $2.088(1.5)$ & $1.225(1.2)$ & \\
LRSPINC & $0.181(2.3)$ & $0.228(1.6)$ & $-0.293(2.8)$ & \\
RSP & & & & $-0.053(.8)$ \\
LRESFAC & $0.029(1.8)$ & $0.159(5.6)$ & $0.216(10.4)$ & $0.171(10.8)$ \\
PFEM & $-1.885(8.4)$ & $-0.270(.7)$ & $1.098(3.8)$ & $-0.242(1.1)$ \\
PMIN & $-0.311(1.0)$ & $-0.262(.5)$ & $0.427(1.1)$ & $-0.260(.9)$ \\
ALUMSTU & $0.811(17.9)$ & $-0.222(2.8)$ & $0.257(4.4)$ & $0.279(6.4)$ \\
MED & $0.177(3.8)$ & $0.385(4.8)$ & $0.104(1.8)$ & $0.298(6.6)$ \\
PERUNDER & $0.659(6.8)$ & $0.122(.7)$ & $0.200(1.6)$ & $-0.356(3.8)$ \\
RELIG & $0.307(7.8)$ & $0.168(2.4)$ & $-0.005(.1)$ & $0.064(1.7)$ \\
& & & & & \\
R ${ }^{2}$ & 0.817 & 0.467 & 0.707 & 0.751 \\
$\mathbf{n}$ & 2079 & 2081 & 2076 & 2079 \\
\hline
\end{tabular}

${ }^{a}$ also included in each model is an intercept term and dichotomous variable for the non-reporting of various variables. 


\section{Table 4 continued}

GAIN TAX

Maximum marginal capital gains tax rate in the calendar year

EST TAX Maximum marginal estate tax rate in the year

CORP TAX

TIER 1

TIER2

TIER3

SENG $^{\mathrm{a}}$

SBUS $^{\mathrm{a}}$

LENR

LENDSTU

LINCOME

LRSPINC

RSP Maximum marginal corporate tax rate in the year

1 if rated in the rest of the first tier of national research univ., 0 if otherwise

1 if rated in the rest of the second tier of national research univ., 0 if otherwise

1 if rated in the rest of the third tier of national research univ., 0 if otherwise

(The omitted group is institutions ranked in the top 25 by USNWR)

Share of degrees granted in engineering fields in the year

Share of degrees granted in business fields in the year

Logarithm of full-time equivalent enrollment in the year

Logarithm of real endowment per full-time equivalent student in the year

Logarithm of real median family income in the year

Logarithm of the ratio of Standard and Poor's index to median family income in the year

Real value of Standard and Poor's index in the year

LRESFAC

PFEM $^{\mathrm{a}}$

PMIN $^{\mathrm{a}}$

Logarithm of real research expenditures per faculty member in the year

Share of students that are female in the year

ALUMSTU $^{\mathrm{a}}$

MED

Share of students that are underrepresented minority in the year

Logarithm of the ratio of alumni to students in the year

PERUNDER $^{\mathrm{a}}$

1 if the university has a medical college, 0 if otherwise

RELIG

Share of students that are undergraduates

1 if the university is affiliated with a religious denomination, 0 if otherwise

See the appendix for the sources for each variable.

${ }^{a}$ A dichotomous variable is entered into the equation, which takes a value of 1 when the variable is not reported, and 0 if it is reported. 


\section{Table 5}

Logarithm of Share/(1-Share) Equations for Sources of Annual Giving:

78 Private Research Universities 1968-69 to $1998-99^{a}$

(absolute value of t-statistics in parentheses)

\begin{tabular}{|c|c|c|c|c|}
\hline & Alumni Giving & $\frac{\text { Other Individual }}{\text { Giving }}$ & $\frac{\text { Foundation }}{\text { Giving }}$ & Corporate Giving \\
\hline GAIN TAX & $-0.003(.3)$ & $-0.021(1.5)$ & $0.003(.3)$ & $0.013(1.5)$ \\
\hline EST TAX & $-0.005(.5)$ & $0.003(.3)$ & $0.016(1.7)$ & $-0.027(3.6)$ \\
\hline CORP TAX & $-0.008(1.0)$ & $-0.003(.2)$ & $0.006(.7)$ & $-0.010(1.5)$ \\
\hline CEO & $0.008(3.8)$ & $-0.001 \quad(.2)$ & $-0.007(3.3)$ & $-0.006(3.4)$ \\
\hline TIER1 & $-0.065(.6)$ & $-0.052(.4)$ & $-0.036(.3)$ & $-0.090(1.0)$ \\
\hline TIER2 & $-0.342(3.4)$ & 0.454 (3.3) & $-0.035(.4)$ & $-0.361(4.4)$ \\
\hline TIER3 & $-0.217(1.9)$ & $0.111(.7)$ & $-0.053(.5)$ & $-0.042(.5)$ \\
\hline SENG & $0.280(1.3)$ & $-1.895(6.4)$ & $-0.822(3.7)$ & $2.269(12.7)$ \\
\hline SBUS & $-0.245(.8)$ & $-0.027 \quad(.1)$ & $-0.665(2.3)$ & $1.065(4.4)$ \\
\hline LENR & $0.392(10.1)$ & $-0.441 \quad(8.4)$ & $0.129(3.4)$ & $0.290(9.2)$ \\
\hline LENDSTU & $0.013(.6)$ & $-0.020(.7)$ & $0.203(9.5)$ & $-0.141(8.1)$ \\
\hline LINCOME & $0.050(.0)$ & $1.890(1.1)$ & $1.385(1.1)$ & $-3.102(3.0)$ \\
\hline LRSPINC & $0.083(.8)$ & $0.136(1.0)$ & $-0.470(4.4)$ & $0.024(.3)$ \\
\hline LRESFAC & $-0.148(6.9)$ & $0.025(.9)$ & $0.085(4.0)$ & $0.030(1.7)$ \\
\hline PFEM & $-2.312(7.8)$ & $-0.152(.4)$ & $1.519(5.2)$ & $-0.649(2.7)$ \\
\hline PMIN & $-0.260(.6)$ & $-0.097 \quad(.2)$ & $0.706(1.8)$ & $-0.363(1.1)$ \\
\hline ALUMSTU & 0.698 (11.7) & $-0.581(7.3)$ & $0.089(1.5)$ & $0.061(1.3)$ \\
\hline MED & $-0.109(1.8)$ & $0.198(2.4)$ & $-0.162(2.7)$ & $0.078(1.6)$ \\
\hline PUND & $0.723(5.7)$ & $0.007(.0)$ & $0.111(.9)$ & $-0.542(5.2)$ \\
\hline RELIG & $0.172(3.3)$ & $0.017(.2)$ & $-0.182(3.6)$ & $-0.098(2.3)$ \\
\hline $\mathbf{R}^{2}$ & 0.322 & 0.135 & 0.175 & 0.346 \\
\hline $\mathbf{n}$ & 2081 & 2083 & 2077 & 2081 \\
\hline
\end{tabular}

${ }^{a}$ also included in each model is an intercept term and dichotomous variable for the non-reporting of various variables. 


\section{Table 6}

Logarithm of Real Giving Used For Various Purposes:

78 Private Research Universities 1968-69 to 1998-99a (absolute value of t-statistics in parentheses)

\begin{tabular}{|c|c|c|c|}
\hline & Current & Fndoumont & Buildings and \\
\hline & 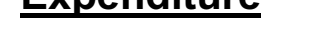 & alluoverime & cquipmentil \\
\hline GAIN TAX & $-0.009(1.3)$ & $-0.032(2.9)$ & -0.020 \\
\hline EST TAX & $0.002(.4)$ & $0.011(1.2)$ & $-0.002(.1)$ \\
\hline CORP TAX & $0.005(.9)$ & $-0.002(.2)$ & $0.009(.8)$ \\
\hline CEO & $0.004(2.9)$ & $0.006(2.5)$ & $0.003(1.1)$ \\
\hline TIER1 & $-0.152(2.2)$ & $0.096(.8)$ & $-0.409(2.7)$ \\
\hline TIER2 & $-0.375(5.8)$ & $0.014(.1)$ & $-0.379(2.7)$ \\
\hline TIER3 & $-0.389(5.4)$ & $-0.215(1.8)$ & $-0.601(3.8)$ \\
\hline SENG & $-0.308(2.2)$ & $-1.176(5.0)$ & $0.822(2.6)$ \\
\hline SBUS & $-0.288(1.5)$ & $-0.086(.3)$ & $0.980(2.4)$ \\
\hline LENR & $0.564(22.6)$ & $0.773(18.1)$ & $0.706(12.8)$ \\
\hline LENDSTU & $0.339(24.6)$ & $0.729(29.6)$ & $0.435(14.3)$ \\
\hline LINCOME & $0.801(1.0)$ & $2.714(2.0)$ & $-0.903(.5)$ \\
\hline LRSPINC & $0.007(.1)$ & $-0.235(2.0)$ & 0.458 (3.0) \\
\hline LRESFAC & 0.157 (11.5) & $0.168(7.2)$ & $0.178(5.9)$ \\
\hline PFEM & $0.021(.1)$ & $-0.774(2.4)$ & 1.307 (3.1) \\
\hline PMIN & $0.767(3.0)$ & $-0.529(1.1)$ & $-2.827(4.8)$ \\
\hline ALUMSTU & $0.392(10.2)$ & $0.044(.7)$ & $-0.066(.8)$ \\
\hline MED & $0.424(10.9)$ & $-0.010(.2)$ & $0.008(.1)$ \\
\hline PERUNDER & $0.126(1.5)$ & 0.577 (4.2) & $-0.159(.9)$ \\
\hline RELIG & $0.027(.8)$ & $0.301(5.4)$ & $0.320(4.4)$ \\
\hline $\mathbf{R}^{2}$ & 0.797 & 0.701 & 0.403 \\
\hline $\mathbf{n}$ & 2080 & 2034 & 2013 \\
\hline
\end{tabular}

${ }^{a}$ also included in each model is an intercept term and dichotomous variable for the non-reporting of various variables. 


\section{Table 7}

Logarithm of Share/(1-Share) Equations for Various Uses of Giving:

78 Private Research Universities 1968-69 to 1998-99a (absolute value of t-statistics in parentheses)

\begin{tabular}{lcccc} 
& \multicolumn{1}{c}{$\begin{array}{c}\text { Current } \\
\text { Expenditure }\end{array}$} & Endowment & Buildings and \\
\hline Equipment \\
GAIN TAX & $0.016(1.5)$ & $-0.021(1.7)$ & $-0.002(.1)$ \\
EST TAX & $-0.003(.3)$ & $0.011(1.0)$ & $-0.012(.9)$ \\
CORP TAX & $-0.001(.1)$ & $-0.006(.6)$ & $0.002(.1)$ \\
CEO & $-0.004(1.7)$ & $0.002(.8)$ & $-0.002(.6)$ \\
TIER1 & $-0.070(.7)$ & $0.301(2.4)$ & $-0.218(1.4)$ \\
TIER2 & $-0.222(2.2)$ & $0.361(3.1)$ & $-0.014(.1)$ \\
TIER3 & $-0.014(.1)$ & $0.160(1.2)$ & $-0.162(1.0)$ \\
SENG & $0.213(1.0)$ & $-0.947(3.7)$ & $1.355(4.2)$ \\
SBUS & $-0.437(1.5)$ & $0.056(.2)$ & $1.116(2.6)$ \\
LENR & $-0.106(2.7)$ & $0.211(4.5)$ & $0.101(1.8)$ \\
LENDSTU & $-0.239(11.2)$ & $0.379(14.1)$ & $-0.004(.1)$ \\
LINCOME & $-0.261(.2)$ & $2.530(1.7)$ & $-2.630(1.4)$ \\
LRSPINC & $-0.196(1.9)$ & $-0.410(3.2)$ & $0.419(2.7)$ \\
LRESFAC & $0.011(.5)$ & $0.004(.1)$ & $0.031(1.0)$ \\
PFEM & $-0.027(.1)$ & $-0.921(2.7)$ & $1.602(3.7)$ \\
PMIN & $2.026(4.8)$ & $-0.627(1.2)$ & $-3.226(5.2)$ \\
ALUMSTU & $0.380(6.4)$ & $-0.231(3.3)$ & $-0.293(3.3)$ \\
MED & $0.416(7.0)$ & $-0.328(4.6)$ & $-0.296(3.3)$ \\
PUND & $-0.030(.2)$ & $0.473(3.2)$ & $-0.342(1.8)$ \\
RELIG & $-0.230(4.5)$ & $0.220(3.6)$ & $0.154(2.1)$ \\
R 2 & 0.125 & 0.188 & 0.100 \\
$\mathbf{n}$ & 2078 & 2035 & 2015 \\
\hline
\end{tabular}

${ }^{a}$ also included in each model is an intercept term and dichotomous variable for the non-reporting 
Table 8

Comparison of Cornell's and Duke's actual shares of giving from each source in 1997-98 with each's predicted values using the share model estimates*

\begin{tabular}{lcccc}
$\begin{array}{l}\text { Share of giving } \\
\text { from }\end{array}$ & $\begin{array}{c}\text { Cornell } \\
\text { actual }\end{array}$ & $\begin{array}{c}\text { Cornell } \\
\text { predicted }\end{array}$ & $\begin{array}{c}\text { Duke } \\
\text { predicted }\end{array}$ & $\begin{array}{c}\text { Duke } \\
\text { actual }\end{array}$ \\
\hline Alumni & 0.505 & 0.382 & 0.312 & 0.168 \\
Other Individuals & 0.223 & 0.232 & 0.195 & 0.157 \\
Foundations & 0.145 & 0.220 & 0.233 & 0.265 \\
Corporations & 0.120 & 0.151 & 0.168 & 0.354 \\
\hline
\end{tabular}

* Using the estimates obtained when the sample was restricted to the 30 private research universities that typically are ranked among the top national institutions 
Figure 1

Share from alumni (unweighted averages)

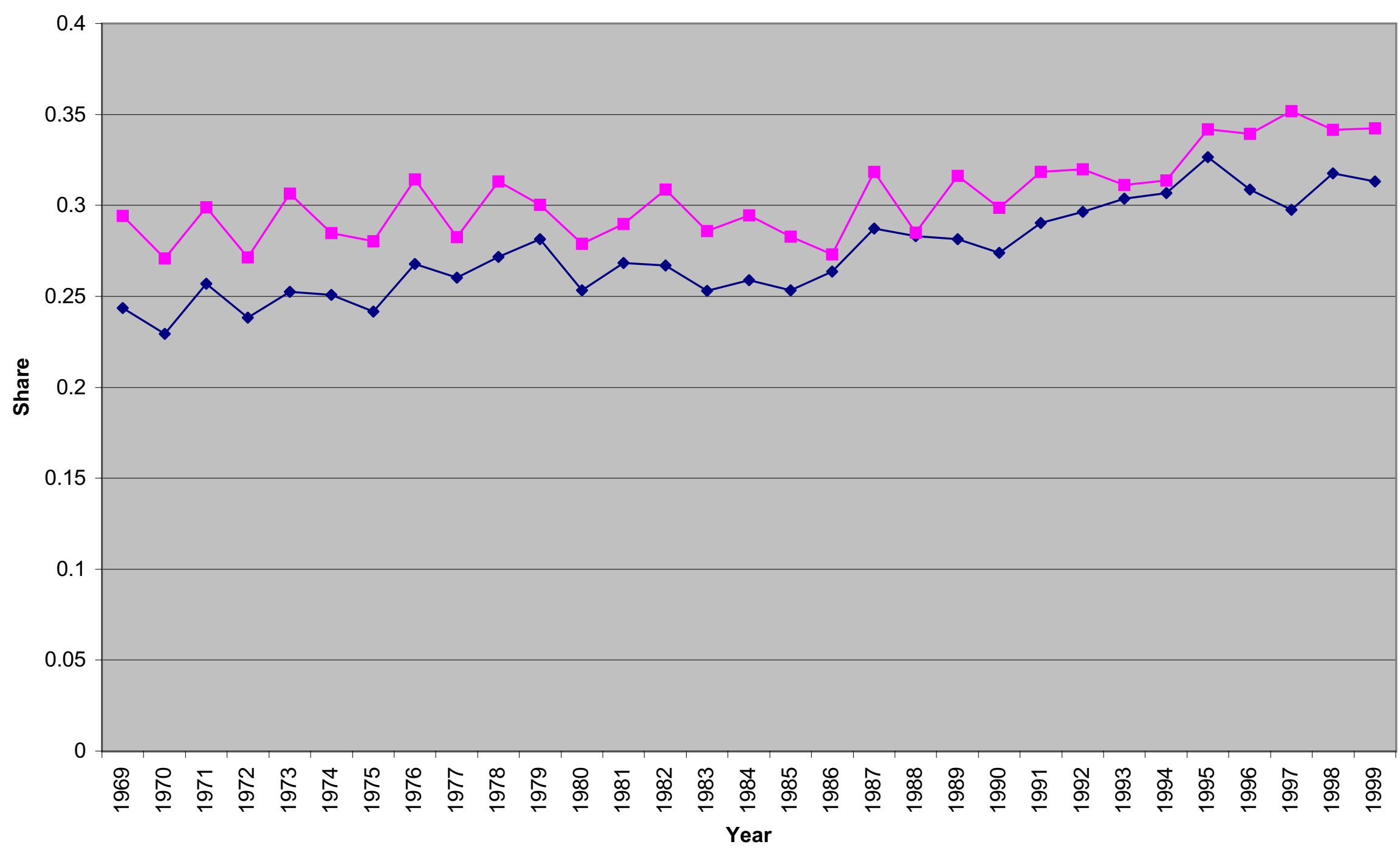

$\rightarrow$ Share from alumni (54)

- - Share from alumni (26) 
Figure 2

Share from other individuals (unweighted averages)

$\longrightarrow$ Share from other individuals (54) Share from other individuals (26)

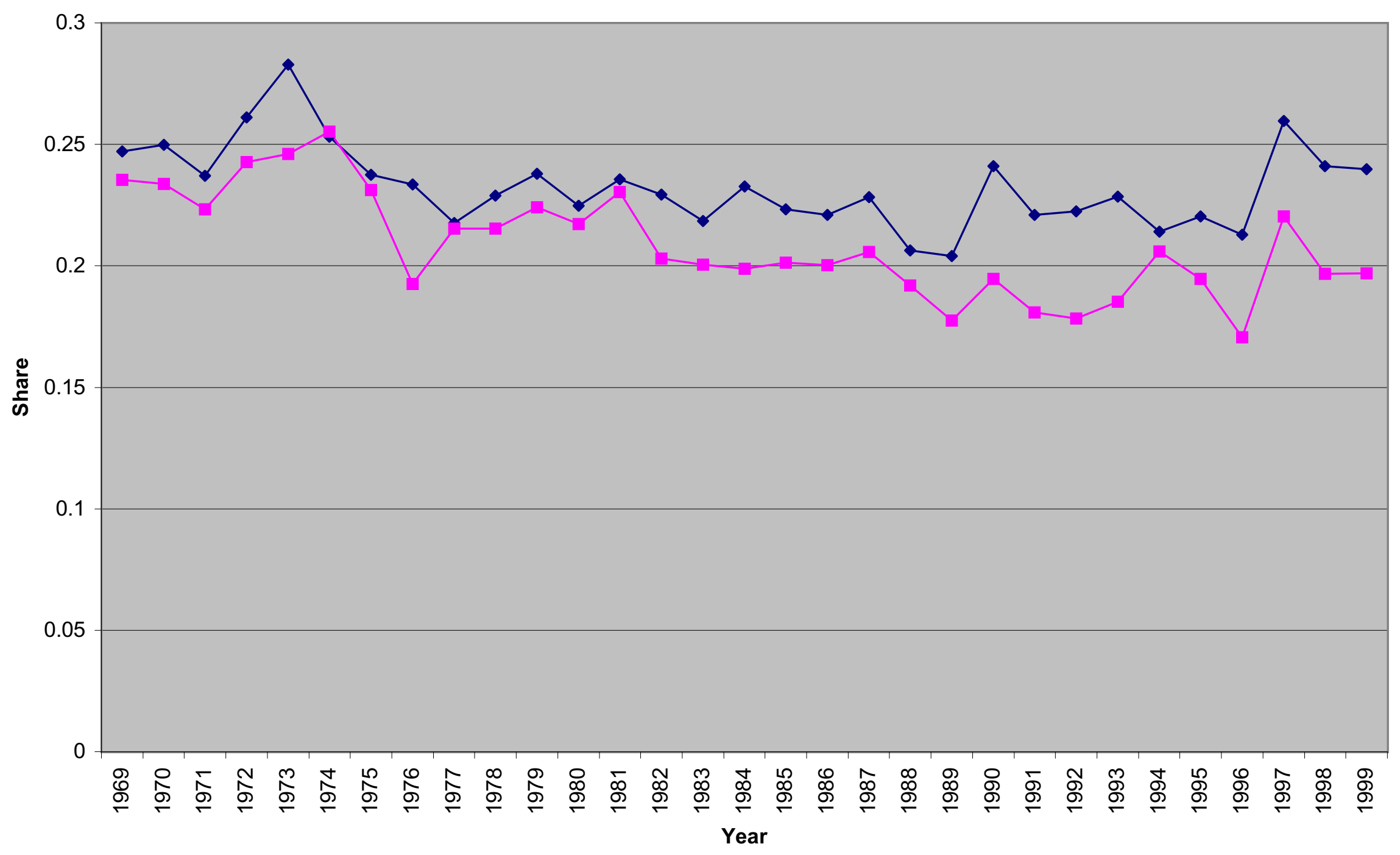


Figure 3

Share from corporations (unweighted averages)

$\neg$ Share from corporations (54)

- Share from corporations(26)

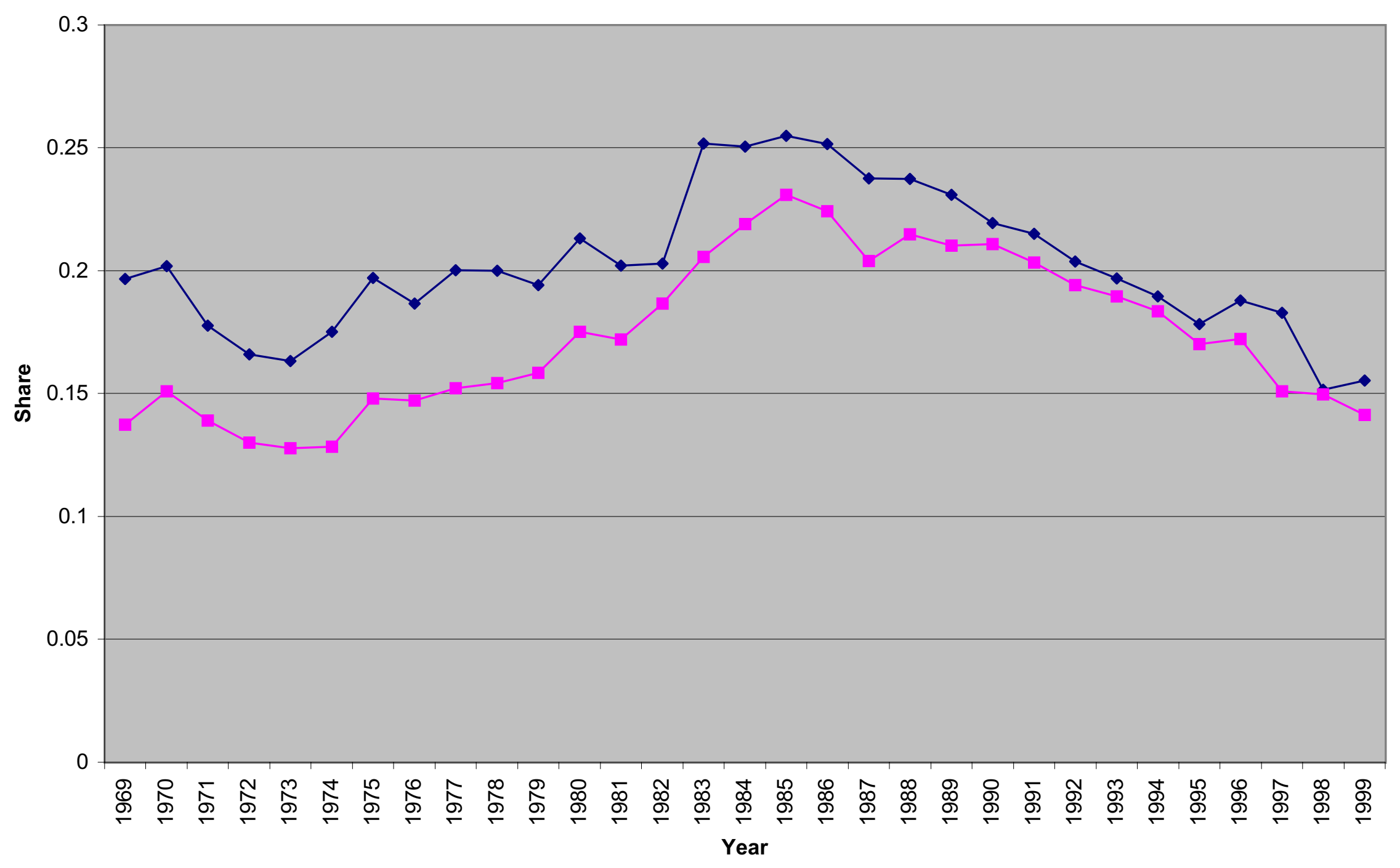


Figure 4

Share from foundations (unweighted average)

$\neg$ Share from foundations (54)

- Share from foundations(26)

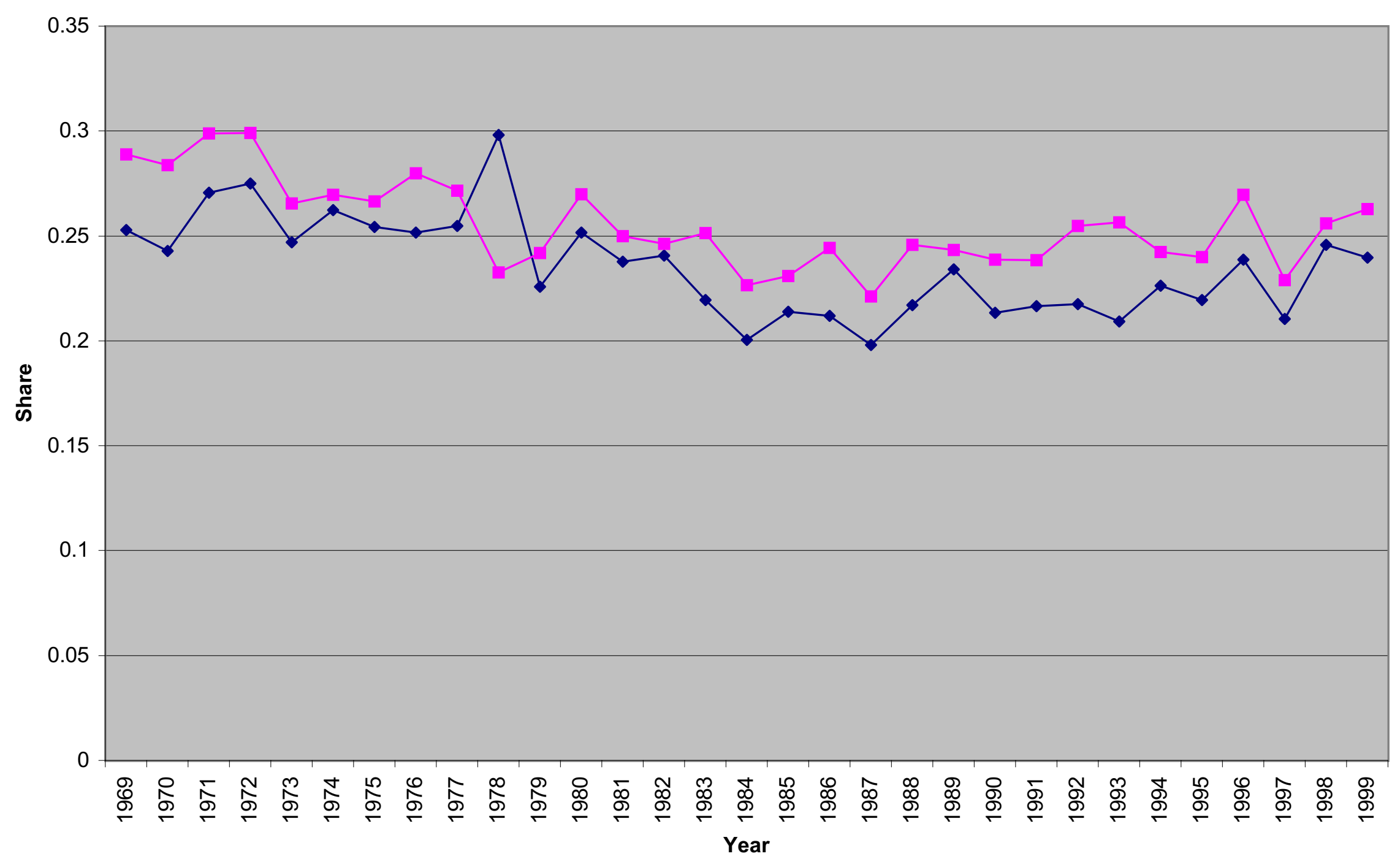


Figure 5

Shares to current expenditures (unweighted averages)

$\longrightarrow$ Share to current expenditures (54)

- Share to current expenditures(26)

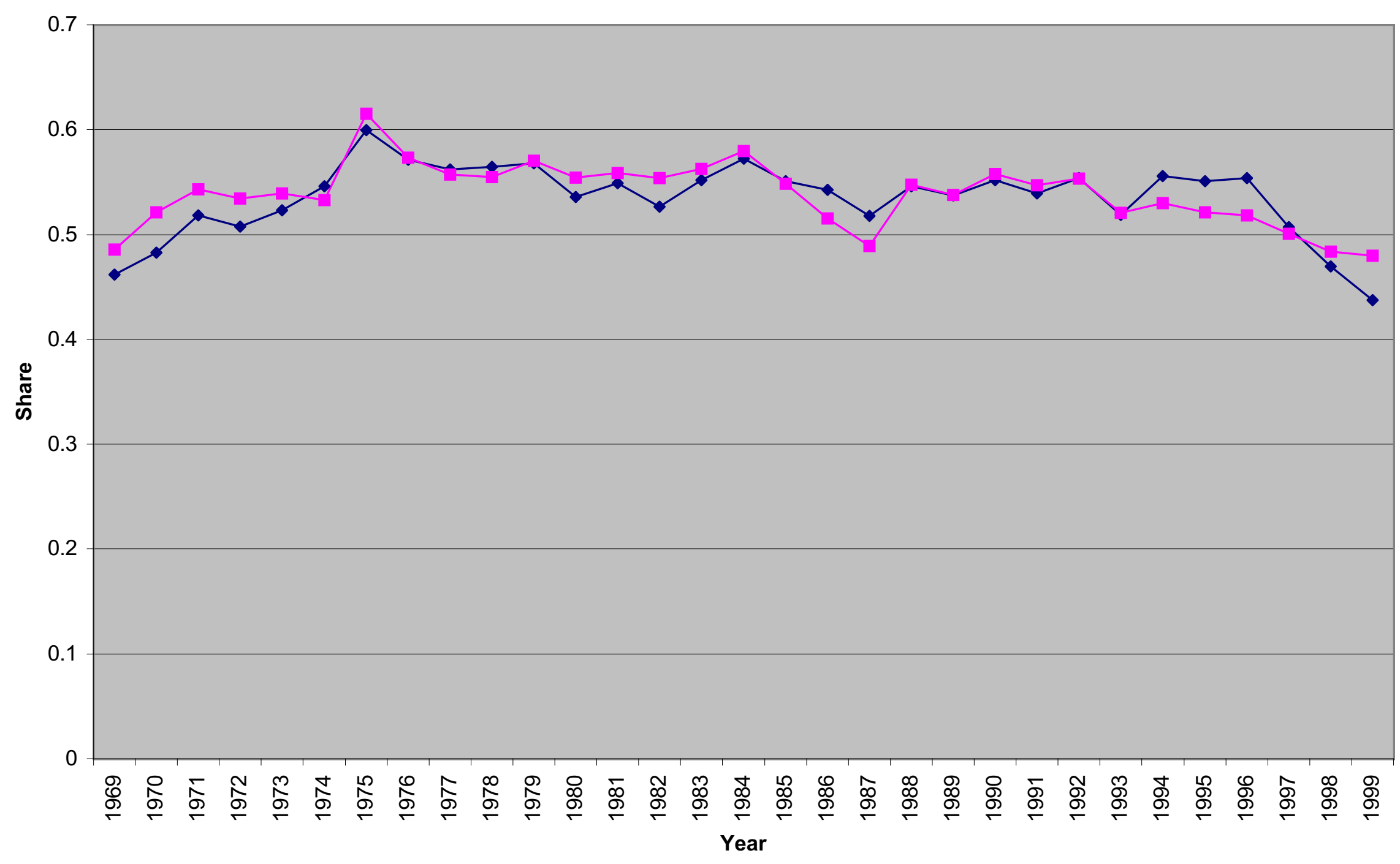


Figure 6

Share to buildings/equipment (unweighted averages)

$\rightarrow$ Share to buildings and equipment (54)

- Share to buildings and equipment(26)

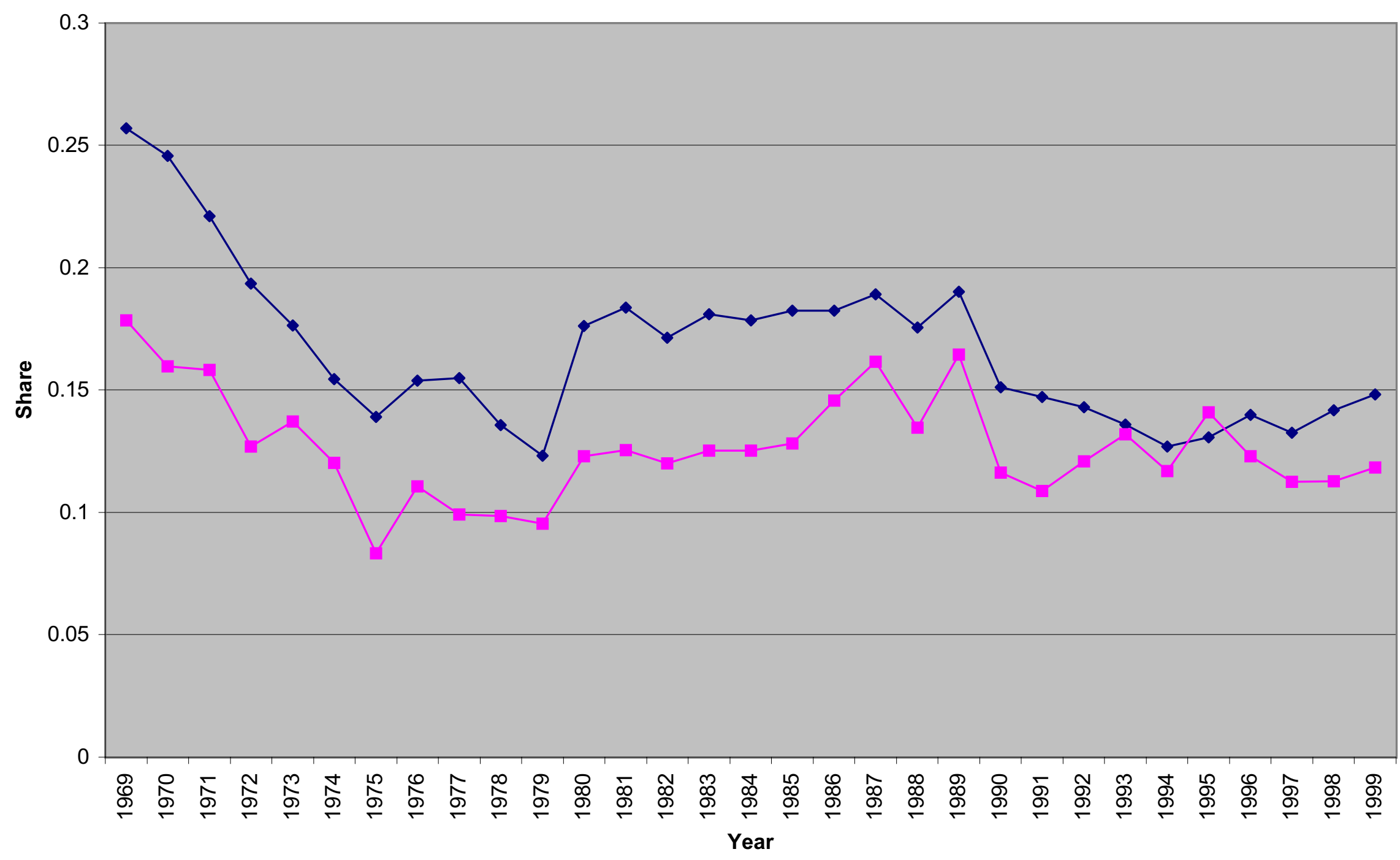


Figure 7

Share to endowment (unweighted average)

Share to endowment (54)

Share to endowment(26)

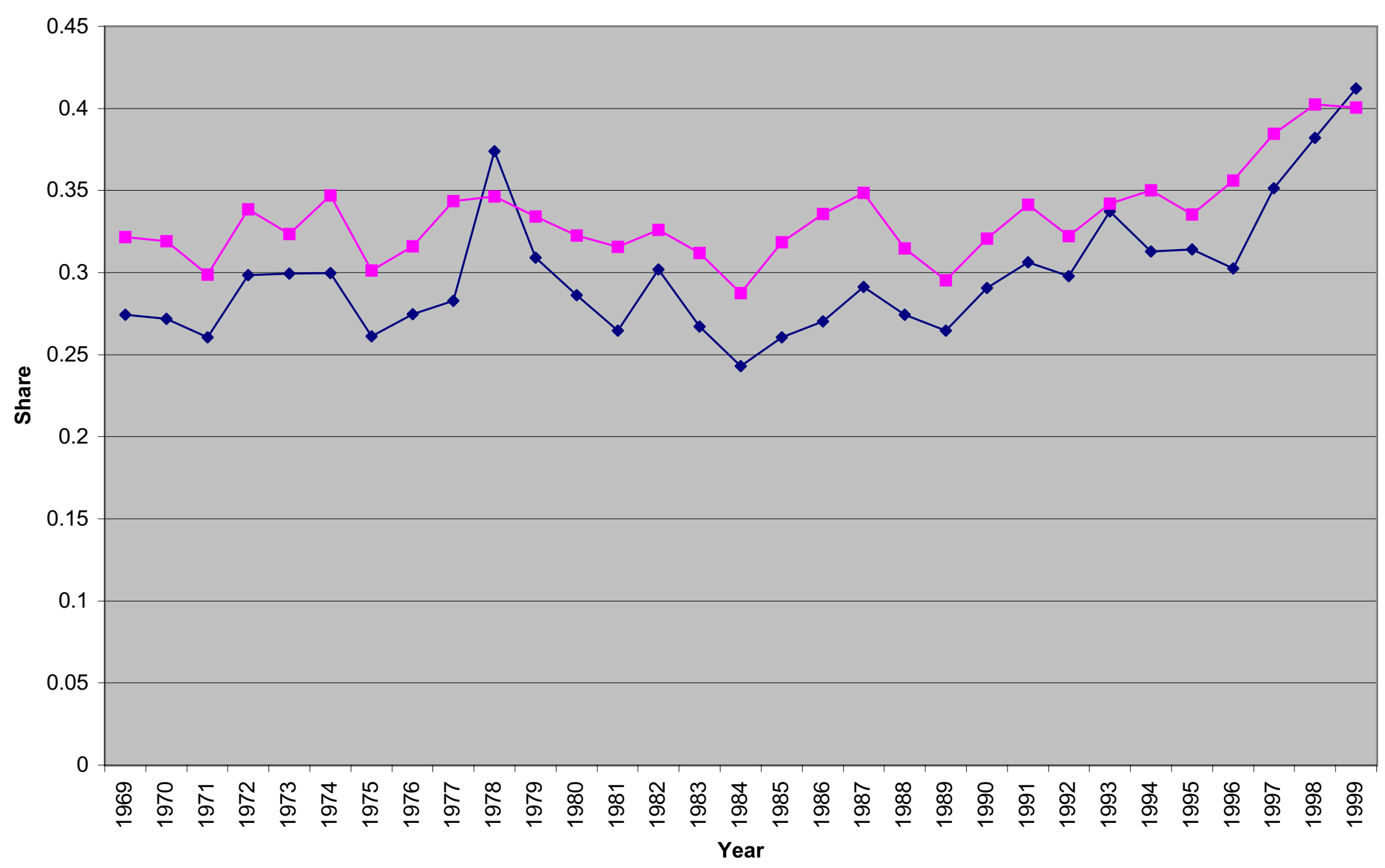




\section{Appendix Table 1 \\ Explanation for Sources and Calculations of Independent Variables}

Source

\section{Calculations}

GAIN TAX "C40. Federal Capital Gaines Tax Rates," Facts and Figures on Government Reported as percentage Finance, 34th Edition

EST TAX "C39. Federal Transfer (Estate and Gift) Marginal Rate Ranges," Facts and Reported as percentage Figures on Government Finance, 34th Edition

CORP TAX "C34. Federal Corporation Income Tax Rates," Facts and Figures on Government Finance, 34th Edition

CEO Forbes Magazine, Data for 1968-69 to 1998-99 was generously provided by Professor Kevin J. Murphy of Southern California University.

$\begin{array}{ll}\text { SENG }^{c} & \text { WebCaspar - "IPEDS Completions Survey" } \\ \text { SBUS }^{\mathbf{c}} & \text { WebCaspar - "IPEDS Completions Survey" } \\ \text { LENR } & \text { VSE Survey } \\ \text { LENDSTU } & \text { VSE Survey }\end{array}$

LRINCOME "Table F-11, Family Income for Householder Whose Age is between 45 and 54," Economic Report of the President 1999

RSPINC Economic Report of the President 1999

\section{LRESFAC ${ }^{c}$ WebCaspar}

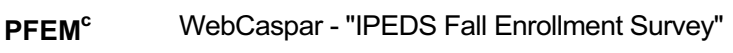

PMIN $^{\mathbf{C}} \quad$ WebCaspar - "IPEDS Fall Enrollment Survey"

ALUMSTU ${ }^{c}$ VSE Survey

PUND $^{c} \quad$ WebCaspar - "IPEDS Salaries, Tenure, and Fringe Benefits of Full-Time Instructional Faculty Survey," \& "Survey of Scientific and Engineering Expenditures at Universities and Colleges"

TIER 1/2/3 U.S. News and World Report

MED U.S. News and World Report listings of Medical Colleges

RELIG From college listings in U.S. News and World Report

Reported as percentage

Counted number of degrees earned by current Forbes 500 s CEOs from an undergraduate or MBA program of the institutions in our sample

Degrees awarded for engineering divided by total degrees awarded (all levels)

Degrees awarded for business divided by total degrees awarded (all levels)

As reported by VSE (all students)

Endowment divided by current enrollment (endowment taken as given by VSE, with exceptions noted below $^{\mathrm{a}}$ )

Standard and Poor's annualized values divided by income as reported above

R\&D expenditures divided by number of faculty

Enrolled female students divided by total students (part time students discounted 2/3)

Enrolled minority students (Black or American Indian/Alaskan Native) divided by total students (part time students discounted $2 / 3$ )

Alumni on record divided by total enrollment

Undergraduates divided by total enrollment (part time students discouted $2 / 3$ )

Ranked in the top 25 is the omitted class. Remaining 1st quartile/1st tier, then TIER1=1; Quartile 2/Tier2, then TIER2=1, same for tier 3. Otherwise, all are $0 .{ }^{\text {b }}$

1 if university has a medical college, 0 otherwise

1 if university has a religious affiliation listed, 0 otherwise

${ }^{a}$ Occassionally, endowment data reported by VSE appeared misreported (differing from previous and subsequent years by significant amounts). We have replaced these endowment values by endowment as reported by WebCaspar. These values better matched the trend of previous and subsequent years.

The replaced values are: American Univ. (1983-85, 1994), Boston Univ. (1971-73), Brigham Young Univ. (1970-73), Brown (1974), Catholic Univ. of America (1985-86, 1988-92, 1994-96), Univ. of Chicago (1975, 1978), Clark Univ. (1971), Drexel Univ. (1979), Duquesne Univ. (1976), Emory Univ. (1993-95), Fordham Univ. (1976-80, 1986, 1990-96), George Washington Univ. (1970-74), Georgetown Univ.(1970-72), Harvard Univ.(1970-83), Howard Univ. (1971-79, 1985-86, 1991, 1993, 1995-96), Johns Hopkins Univ. (1978-79), Pepperdine (1971-82), Seton Hall Univ. (1972, 1974-75, 1977-78), University of Southern California (1981), Syracuse (1971-73), Tulane Univ. (1995), Yeshiva Univ. (1980, 1984-87, 1992-96) 
${ }^{\mathrm{b}}$ For years in which tiers were not reported (1989-91) or years in which USNWR survey was not undertaken, all tier variables were set euqal to zero and a dichotomous variable for non-reporting was set equal to one. For all other years this variable was set equal to zero.

${ }^{c}$ When the variable was missing, its value was set euqal to zero and a dichotomous variable was created whose value was set equal to one (and zero in the other years). 
Appendix Table 2

Descriptive Statistics for Independent Variables

\begin{tabular}{lcccc} 
& \multicolumn{2}{c}{ All insts. } & \multicolumn{2}{c}{ Select inst. } \\
& Mean & St. Dev & Mean & St. Dev \\
GAIN TAX & 28.313 & 4.790 & 28.313 & 4.790 \\
EST TAX & 65.516 & 8.152 & 65.516 & 8.152 \\
CORP TAX & 42.000 & 6.650 & 42.000 & 6.650 \\
CEO & 5.163 & 11.384 & 10.450 & 15.568 \\
SENG & 0.190 & 0.196 & 0.157 & 0.135 \\
SBUS & 0.166 & 0.091 & 0.129 & 0.064 \\
LENR & 9.065 & 0.698 & 9.156 & 0.653 \\
LENDSTU & 4.922 & 1.567 & 6.086 & 1.053 \\
LINCOME & 5.789 & 0.073 & 5.789 & 0.073 \\
LRSPINC & -4.917 & 0.413 & -4.917 & 0.413 \\
LRESFAC & -1.146 & 1.543 & -0.057 & 0.708 \\
PFEM & 0.412 & 0.136 & 0.393 & 0.116 \\
PMIN & 0.244 & 0.130 & 0.240 & 0.101 \\
ALUMSTU & 1.769 & 0.458 & 1.982 & 0.309 \\
PUND & 0.664 & 0.136 & 0.669 & 0.142
\end{tabular}




\section{Appendix Table 3}

Logarithm of Share/(1-Share) Equations for Sources of Annual Giving:

30 Private Research Universities 1968-69 to 1998-99 ${ }^{a}$

(absolute value of t-statistics in parentheses)

\begin{tabular}{|c|c|c|c|c|}
\hline & Alumni Giving & $\frac{\text { Other Individu }}{\text { Giving }}$ & Foundation Giving & Corporate Giving \\
\hline GAIN TAX & $0.001(.1)$ & $-0.032(1.3)$ & $0.006(.5)$ & $-0.011(1.1)$ \\
\hline EST TAX & $-0.012(1.0)$ & $0.009(.4)$ & $0.013(1.2)$ & $-0.015(1.6)$ \\
\hline CORP TAX & $-0.021(1.8)$ & $-0.011 \quad(.5)$ & $0.004(.4)$ & $-0.013(1.5)$ \\
\hline CEO & $0.008(3.2)$ & $-0.004 \quad(.9)$ & $-0.008 \quad(3.9)$ & $-0.005(3.0)$ \\
\hline TIER1 & $-0.187(1.7)$ & $-0.028 \quad(.1)$ & $0.265(2.7)$ & $-0.093(1.1)$ \\
\hline TIER2 & $0.465(.6)$ & $0.207(.2)$ & $-0.421 \quad(.6)$ & $-0.130 \quad(.2)$ \\
\hline SENG & $0.373(1.1)$ & $-1.966 \quad(3.4)$ & $0.139(.5)$ & $2.660(10.8)$ \\
\hline SBUS & $1.563(2.6)$ & $-0.670 \quad(.6)$ & $-2.825(5.4)$ & $-0.523(1.2)$ \\
\hline LENR & $0.100(1.5)$ & $-0.207(1.8)$ & $0.246(4.2)$ & $0.265(5.4)$ \\
\hline LENDSTU & $-0.044(1.0)$ & $0.241(3.2)$ & $0.122(3.2)$ & $-0.193(6.0)$ \\
\hline LINCOME & $-0.931(.5)$ & $-1.464 \quad(.5)$ & $-0.209(.1)$ & $0.264(.2)$ \\
\hline LRSPINC & $0.152(1.0)$ & $0.249(.9)$ & $-0.084(.6)$ & $-0.126(1.1)$ \\
\hline LRESFAC & $-0.590(11.4)$ & $0.129(1.4)$ & $0.128(2.8)$ & $0.056(1.5)$ \\
\hline PFEM & $-1.512(4.3)$ & $-0.309 \quad(.5)$ & $-0.038(.1)$ & $-0.300(1.1)$ \\
\hline PMIN & $1.575(1.1)$ & $4.208(1.6)$ & $-1.273(1.0)$ & $-2.300(2.1)$ \\
\hline ALUMSTU & $0.621(5.0)$ & $-0.873(4.1)$ & $0.215(2.0)$ & $0.394(4.3)$ \\
\hline MED & $0.334(3.4)$ & $0.038(.2)$ & $0.024(.3)$ & $0.008(.1)$ \\
\hline PUND & $0.664(4.3)$ & $-0.369(1.4)$ & $0.120(.9)$ & $-0.452(4.0)$ \\
\hline RELIG & $0.085(.9)$ & $-0.189(1.1)$ & $0.261(3.0)$ & $0.158(2.1)$ \\
\hline $\mathbf{R}^{2}$ & 0.386 & 0.105 & 0.131 & 0.425 \\
\hline $\mathbf{n}$ & 903 & 903 & 903 & 903 \\
\hline
\end{tabular}

${ }^{a}$ also included in each model is an intercept term and dichotomous variable for the non-reporting of various variables. 